\title{
REWORK RISKS TRIGGERS IN THE NIGERIAN CONSTRUCTION INDUSTRY: A VIEW OF BUILT ENVIRONMENT PROFESSIONALS
}

\author{
Emmanuel Chidiebere Eze \\ Federal University of Technology Minna, Nigeria \\ E-mail: emmanueleze001@gmail.com \\ John Ebhohimen Idiake \\ Federal University of Technology Minna, Nigeria \\ E-mail: idiakeje@futminna.edu.ng \\ Bashir Olanrewaju Ganiyu \\ Federal University of Technology Minna, Nigeria \\ E-mail: bashiroganiyu@futminna.edu.ng \\ Submission: 07/09/2017 \\ Accept: 06/03/2018
}

\section{ABSTRACT}

Rework is systemic and a recurring decimal, and it is triggered by several factors whose emergence create scenarios that degrades project cost, quality and schedule performance, and overall project performance. This study therefore examined the perception of construction professionals on the factors that triggers the emergence of rework in the Nigerian construction industry. This was achieved by determining the predominant rework triggers that affect project performance, identifying rework triggers in which the professionals view varies significantly, and examining the category of rework risks triggers that contribute more to rework incidences. The study adopted a quantitative survey approach in which structured questionnaire was adopted as the research instrument. Mean item score was used in ranking the professionals perception on rework triggers, and KruskalWallis $\mathrm{H}$ test was used to identify the variables in which the professionals view varies. The study concluded that: contractorrelated and design-related causes are the major categories of rework risks triggers. 
INDEPENDENT JOURNAL OF MANAGEMENT \& PRODUCTION (IJM\&P)

http://www.ijmp.jor.br

v. 9, n. 2, April - June 2018

ISSN: 2236-269X

DOI: 10.14807/ijmp.v9i2.729

Unclear instruction to workers, Shortage of skilled supervisors, incomplete and inaccurate information are the predominant triggers of rework. The professionals view varies significantly on nine factors which cut across the four categories of rework triggers. It was recommended that there is need for clarity, effectiveness and timeliness of instruction and information dissemination among project participants, and the use of skilled and experienced professionals, skilled supervisors and proper implementation of quality management practices by both the design consultant and contractor throughout the project's phases.

Keywords: Built environment professionals, Construction Industry, Nigeria, Rework, Risks triggers

\section{INTRODUCTION}

The construction industry is the driving force behind socio-economic development of any nation (SAIDU; SHAKANTU, 2016a). The industry is the means through which countries upgrade their national economies (ANIL; DANIELRAJ, 2016). Construction industry takes huge amount of money, time and energy (MESHKSAR, 2012). It is among the major industries that contribute to economic growth and civilization; as such, its importance is approved in all communities (MESHKSAR, 2012). The activities of the industry improves the quality of life by providing infrastructures such as buildings, roads, hospital, schools among other facilities (SAIDU; SHAKANTU, 2016c ).

In spite of the significance of the construction industry, it is faced with the problems of poor financial performance, high cost of project delivery, poor quality and material waste, and failure to deliver value to clients on schedule (ABDULRAHMAN et al., 2013; SAIDU; SHAKANTU, 2016c; ANIL; DANIELRAJ, 2016). Consequently, the industry has been extensively criticized for poor performance and ineffective productivity (SIMPEH, 2012). The cost and schedule overruns often experienced in the construction projects delivery is directly and significantly attributable to rework factors (HWANG et al., 2009; ANIL; DANIELRAJ, 2016).

Rework is one of the major factors responsible for the setback experienced in the industry (SIMPEH, 2012; ANIL; DANIELRAJ, 2016). Rework is the main contributor to time wastage and schedule overruns which ultimately impact on cost, resources and quality (LOVE; EDWARDS, 2004a; ANIL; DANIELRAJ, 2016). Love 
(2002a) opined that rework would naturally increase total project costs by $12.6 \%$. Similarly, Davis et al (1989) reported that rework could cause additional cost to construction of up to $12.4 \%$ of the total project cost.

Enshassi et al. (2017) carried out a studied which was aimed at identifying the factors that contribute to Rework and their Impact on Construction Projects Performance in Palestine. The study examined the views of contractors, consultants and project owners using questionnaire survey, and concluded that contractor's related rework causes and human related rework causes are the major categories which impact on project performance.

Mahamid (2016) analysed the cost and causes of rework in residential building projects in West Bank, Palestine. The study adopted questionnaire survey among 78 contractors. The study revealed that construction projects are mostly affected by client and contractors related factors.

Ajayi and Oyeyipo (2015) studied the effect of rework on project performance in building project in Lagos State, Nigeria. The study adopted questionnaire survey with 52 construction professionals, and found out that rework impact on project cost and project schedule. The most ranked causes of rework under client related, design related, and subcontractor related causes were Poor communication with design consultant, Use of poor quality materials, poor workmanship, lack of experience and knowledge of design and construction process, and incomplete design as at time of design.

Anil and Danielraj (2016) carried out a study whose aim was to determine the underlying causes of rework during construction, and their impact on the overall project performance in order to develop effective prevention strategies in India construction industry. The study adopted a questionnaire survey among professionals, and found out that poor communication between design consultants and clients, deviation from drawings, poor coordination of resources, setting out errors, and low-skilled labour employed by subcontractors are the major causes of rework and these cut across the activities of the client, consultants, and contractors.

It is vital to know that these studies did not compare the responses of the professional regarding the factors that triggers the occurrence of rework. It is based on this, that this study assessed the relationship that exists among construction professionals view regarding the factors that triggers the occurrence of rework. The aim of this study is to examine the perception of construction professionals on the 
INDEPENDENT JOURNAL OF MANAGEMENT \& PRODUCTION (IJM\&P)

http://www.ijmp.jor.br

v. 9, n. 2, April - June 2018

ISSN: 2236-269X

DOI: 10.14807/ijmp.v9i2.729

factors that triggers the emergence of rework in the Nigerian construction industry, with a view to ascertaining factors where their views differs significantly.

The specific objectives of this study are; to determine the predominant rework triggers that affect project performance, to identify rework triggers in which the professionals view varies significantly, and to examine the category of rework risks triggers that contribute more to rework incidences. The hypothesis that guided this study is $\mathrm{H}_{1}$ : there is no significant difference in the perception of the different professions regarding the rework risks triggers.

Constructions professionals do recognize that rework have considerably impact on project performance (LOVE; EDWARDS, 2004a). Improved quality requires an understanding of the root causes of the rework (LOVE et al., 1999a). Rework is a major problem that has befallen the construction industry of Nigeria and better understanding of the factors that trigger their emergence will assist the project managers and other participants to ascertain the most effective techniques to improve or eliminate rework.

\section{LITERATURE REVIEW}

\subsection{Rework Risk Trigger}

An event or condition that causes a risk to occur is known as risk trigger. Risks are the potential for something usually negative to happen (SPACEY, 2016). According to Spacey (2016), a trigger is root cause of an event. Based on this definition, Rework risks triggers are factors that can cause rework to emerge in construction work, and this could happen throughout the phases of construction projects. These triggers are causes, factors, variables, events, or occurrences that could result to rework.

Rework occurs when a product or service does not meet the requirements of the customer (LOVE et al., 1999a). As a result, the product is distorted in accordance with the requirements of the customers. The production of substandard products or poorly performs services by organisation participating in a project is not intentional; however, errors are accepted as part of human nature (SIMPEH, 2012).

Enshassi et al. (2017) categorized fifty-seven rework factors into Construction process related causes, Materials and equipment supply related causes, Client related causes, Contractor related causes, Human resource capability related 
INDEPENDENT JOURNAL OF MANAGEMENT \& PRODUCTION (IJM\&P)

http://www.ijmp.jor.br

v. 9, n. 2, April - June 2018

ISSN: 2236-269X

DOI: 10.14807/ijmp.v9i2.729

causes, Design related causes, and External environment related causes. The study carried out by Enshassi et al. (2017) revealed that contractor and human resources capacity related factors are the major factors that trigger rework and they have the highest impact on construction projects performance. The root causes of construction rework are categorised into client-related, design-related, and Contractor-related factors (LOVE; EDWARDS, 2004a).

Client factors identified by Palaneeswaran (2006) include: poorly prepared contract documentation; Poor communication with design consultants; inadequate briefing; Lack of client involvement in the project; Lack of funding for site investigation; the inexperience and lack of knowledge of the design and construction processes. Inadequate briefing, Lack of knowledge of construction process, Lack of funding allocated for site investigation are they principal causes of rework that impact on project performance that are related to the project owner (ENSHASSI et al., 2017).

According to Dalty and Crawshaw (1973) poor flow of communication or deficits in the flow of communication among members of the client and design team results in omission and errors being incorporated in contract documentation unnoticed. As such the clients and their project team members must ensure that they communicate and work together amicably; for the projects to be delivered on times or ahead of schedule (WALKER, 1994).

According to Simpeh (2012) lack of coordination and integration of design by the design team have resulted to deficiencies in design; and these have contributed greatly to the causes of rework. Josephson and Hammarlund (1999) supported this view by pointing out that communication problems is primarily the source of designrelated rework in construction. In the same vein, Austin et al. (1994) asserts that poor use of information technology in communicating and managing project information worsens the volume of rework occurring in construction projects.

According to the results of Love and Li (2000), the poorly coordinated and integrated members of the design team delay the exchange of information between them. Design errors and Omission, Incomplete information for design, incomplete design and lack of professionalism are the major causes of design related rework (ENSHASSI et al., 2017). 
INDEPENDENT JOURNAL OF MANAGEMENT \& PRODUCTION (IJM\&P)

http://www.ijmp.jor.br

v. 9, n. 2, April - June 2018

ISSN: 2236-269X

DOI: 10.14807/ijmp.v9i2.729

According to Love et al. (2010), the argument therefore, is that design professionals lack the professionalism due to design fee reduction which has further resulted in production of contract documents that are incomplete and inadequate. This according to Simpeh (2012) leads to rework and may lead to dispute and smear the image of participants in the long run.

The failure to plan work by most supervisors, adequately direct activities and communicate with workers has impact on increasing the volume and costs of rework (SIMPEH, 2012). Enshassi et al. (2017) revealed that attempt to fraud, Competitive pressure / low contract value, Unqualified technically, and Poor quality system as the major contractors related rework causes. The efficiency of the major contractor's construction planning efforts has effect on the success of the projects of the Site management team and subcontractors (FANIRAN et al., 1999; IRELAND, 1985; SIMPEH, 2012; WALKER, 1994).

Project without a quality management system in place essentially increases the cost of project by $10 \%$ due to rework (CUSACK, 1992). Inability to safeguard (or protect) works which implies failure during alteration works to protect certain parts of a building (BARBER et al., 2000; SIMPEH, 2012). Setting-out errors, Poor workmanship, multi-tasking and time pressure (LOVE et al., 1999a; SIMPEH, 2012; JOSEPHSON; HAMMARLUND, 1999).

For the subcontractors, specific rework factors found by: Love and Smith (2003), Love et al. (1999a), Josephson et al. (2002), Oyewobi and Ogunsemi (2010); and Rounce (1998) are damage to other trade work due to carelessness, inadequate supervision, poor choice of materials, poor managerial skills, and low skill level of construction artisans and labour. Poor skill levels of; the client's project manager, the design team and subcontractors (LOVE et al., 2002).

Smallwood (2000) confirmed that clients perceived that late information, poor management of the design activities, poor planning, lack of concern for the environment, low skills level among the workers, and overall poor management were the causes of poor contractor performance. According to Wasfy (2010), the factors that lead to the rework of material and equipment supplies include non-compliance with specifications, untimely deliveries, prefabrication not to project specifications, and unavailability of materials at right time and place when needed. 
Environmental factors that causes rework are Political situation (Siegeconflicts), Economy (Inflation, exchange rates, market), and Physical condition (ENSHASSI et al., 2017). Mahamid (2016) reported that weather and lack of safety are the major environmental causes of rework that affect project performance. The construction environments are confronted with problems related to production, design changes, general quality of materials and quality of work and use of available capacity (MAHAMID, 2016).

Majority of construction projects are faced with a lot of causes that leads to rework, such as; omissions, alteration, failures, proper communication, and inadequate coordination and collaboration between stakeholders (ANIL; DANIELRAJ, 2016). As such, rework have critically influenced the productivity, performance, and finance of a project (ANIL; DANIELRAJ, 2016).

\section{METHODOLOGY}

Quantitative research approach was adopted for data collection, and wellstructured questionnaires were used to collect data on the perception of the various professionals regarding the factors that trigger the emergence of construction rework. The questionnaire was self- administered, by the authors and through the help of trained field assistants who were properly briefed about the research topic and given the necessary information on how to administer the questionnaire

The appropriateness of the questionnaire to meet the study objectives was carried out through a pilot survey. Fellows and Liu (2008) opined that research instrument (questionnaire) should be initially piloted in order to verify whether the questions are intelligible, unambiguous and easy to answer, as well as providing an opportunity to improve the questionnaire and determining the time required in completing the exercise. Twenty (20) of the draft questionnaire were randomly distributed to selected construction professionals, and the final draft was adjusted based on their feedback.

The populations of the study are registered professionals such as: Builders, Quantity surveyors, Architects, and Engineers practicing within Abuja, Nigeria. The total population of this study is 6899 comprising (404 builders, 845 Quantity surveyors, 400 Architects and 5250 Engineers). This number was obtained from the 
register of Abuja chapter of the various professional bodies namely Nigerian Institute of Building (NIOB) for builders, Nigerian Institute of Architects (NIA) for the architects, Nigerian Institute of Quantity Surveyors (NIQS) for quantity surveyors, and Nigerian Society of Engineer (NSE) for engineers. Abuja was selected for this study because it is the administrative headquarters of Nigeria; and it is one of the metropolitan cities in Nigeria with the highest population of Construction professionals practicing in either constructing or consulting firms within the built environment (SAIDU; SHAKANTU, 2016c).

The sample size for this study is 364 , and this was derived by applying the formula by The NEA Research Bulletin (1960), and Krejcie and Morgan (1970) to the population using a $95 \%$ confidence level.

$$
s=X^{2} N P(1-P) \div d^{2}(N-1)+X^{2} P(1-P)
$$

\section{Where;}

$s=$ sample size from finite population

$X=$ based on confidence level 1.96 for $95 \%$ confidence was used for this study

$d=$ Precision desired, expressed as a decimal (i.e. 0.05 for $5 \%$ used for this study

$\mathrm{P}=$ Estimated variance in Population as a decimal (i.e. 0.5 for this study)

$\mathrm{N}=$ total number of population

A total of 195 questionnaires were retrieved out of the 364 distributed. Out of the 195 response received, seven (7) were invalid because of incomplete response, and 188 were properly filled and was considered valid response, this represents a response rate of $51.64 \%$. The 188 valid responses consist of 32 builders, 61 quantity surveyor, 44 Architects, and 51 civil engineers. According to Alreck and Settle (1985), this response rate is considered suitable for a study whose focus is to gain responses from professionals and practitioners within the construction industry.

The questionnaire was based on a 5-point Likert scale and ranges from 1 to 5 , with 5 being the highest. The analysis of the data collected was carried out using means item score, percentages, Kruskal-Wallis $\mathrm{H}$ test. Tables and charts were also used to present the analyzed data. Mean item score was used to analyze and rank the factors that trigger rework incidences. Kruskal-Wallis $\mathrm{H}$ test was used to test the hypotheses in order to determine if there are statistically significant differences in the 
opinions of the respondents. Kruskal-Wallis test was also adopted to ascertain the variables in which the respondents view varies. The rule for accepting or rejecting the hypothesis is;

i. accept hypothesis; if $\mathrm{P}$-value $\geq 0.05$, and

ii. reject hypothesis; if P-value $<0.05$.

These analyses were done using statistical package for social science (SPSS) Version 20

\section{4. RESULTS AND DISCUSSIONS}

\subsection{General Information of Respondents}

The analysis of respondents' information revealed that $48.40 \%$ of the respondents have their years of experience rage from 1-10 years, and 39.89\% have work in the construction industry for 11-20 years. This implies that they are experienced enough to give reliable information that will aid the study. In addition, $29.79 \%$ of the respondents have diploma degree, $46.28 \%$ have Bsc/B.Tech degree and $21.81 \%$ of them are master's degree holders. This implies that they are academically qualified to take active part in this study.

Furthermore, according to the respondents, $73.4 \%$ always keep records of rework incidents, $23.94 \%$ keeps record sometimes, and only $2.66 \%$ of them had never kept rework of rework incidences. Rework incidences cannot be completely attributable to a particular party, they respondents are of the opinion that the activities of contractors contribute most to rework with $37.77 \%$, and that is closely followed by the consultant (31.38\%) and then the client/customer (18.09\%).

Also, the professional qualification of the respondents indicates that, $32.45 \%$ of them are quantity surveyors and are registered with the Nigerian Institute of Quantity Surveyors (NIQS), 17.02\% are builders and are registered with Nigerian Institute of Builders (NIOB), $23.40 \%$ are Architects and belong to Nigerian Institute of architects (NIA), and $27.13 \%$ are Engineers and are members of Nigerian Society of Engineers (NSE).

The high proportion of quantity surveyors implies that they are involved in cost-associated matters such as rework in the construction industry. Similarly, the professional status of the respondents shows that, $21.81 \%$ of the respondents are probationer members of the various professional bodies, $76.06 \%$ are corporate 
members of the various professional bodies, and $2.13 \%$ are fellows of the professional bodies. The high proportion of the corporates members indicates that the respondents are professionally qualified to give an expert opinion on the subject of this study.

\subsection{Normality Test for Rework Risks Triggers}

A normality test was first carried out on the collected data in order to determine the type of test to be done. The essence was to establish the nature of the data (i.e. whether it is parametric or non-parametric). To ascertain this, Ghasemi and Zahediasi (2012) suggested the use of Shapiro-Wilk normality test in studies with sample size of less than 2000 .

The analysis shows that the significant value of all the variables examined is 0.000 , which is less than the 0.05 required criteria for normality. Therefore, the collected data are non-parametric in nature and cannot be examined using normal parametric statistical techniques. This confirms the recommendation of Thode (2002) that Shapiro-Wilk test is the best choice for testing the normality of non-parametric data.

Thus, Kruskal-Walis test; a non-parametric test, which is suitable when there is need to ascertain the significant difference in the perception of three or more categories of respondents, was employed in determining consistency in the opinion of the respondents within the four (4) different professions in the built environment.

\subsection{Comparation of Professionals Perception Regarding Rework Risks Triggers}

Table 1 shows the significant value derived from Kruskal-Wallis $\mathrm{H}$ test conducted on rework risks triggers on building construction projects. Kruskal-Wallis $\mathrm{H}$ test was used to compare the perceptions of construction professionals regarding the rework risks trigger on construction projects. Under the client-related factors, the result revealed that the p-value of one (1) out of the 7 risks factors assessed is less than 0.05 .

This implies that there is a significant difference in the way these respondents from the different professions in the construction industry view this factor. This factor is lack of adequate participation of the client in the project. This difference in view 
INDEPENDENT JOURNAL OF MANAGEMENT \& PRODUCTION (IJM\&P)

http://www.ijmp.jor.br

v. 9, n. 2, April - June 2018

ISSN: 2236-269X

DOI: 10.14807/ijmp.v9i2.729

could be attributed to the individual perception of construction professionals as to the level and experience of the client in construction activities.

The professionals are of the opinion that the engagement of the consultant should relief the client of the responsibility of participating fully in the project, as he may be busy with other investments. However, it is observed that there is a significant relationship in the perception of the respondents on other rework risks triggers as the have their P-value to be greater than 0.05 .

This result is in consonance with the report of Enshassi et al., (2017), who found out that construction experts agrees on the owner related rework causes, as the probability of significance was more than 0.05. Simpeh (2012), also, reported a level of agreement among respondents concerning some client-related factors that contribute to rework.

Similarly, changes requested by the client with a p-value of less than 0.05 , was the only rework risks trigger among the design-related factors in which the perceptions of the categories of professionals differs significantly. The respondents are of the opinion that, although, the client is a major stakeholder and the financier of the project, the design consultants should be able to influence the number and frequencies of changes requested by the client.

Implying that the consultants are in the best position to advise the clients on various design options. Conversely, the perception of other rework triggers were observed to be significant and in agreement as their P-value $>0.05$. Implying that these design-related factors influences the emergence of construction rework which could impact on construction time, cost and resources. This finding is supported by Enshassi et al., (2017), who reported that there is agreement among construction participants on the probability of occurrence of rework causes related to design.

Evidently, respondents were in disagreement about six (6) factors under the contractor-related factors. These factors are errors in setting out, inadequate training and inexperience, poor planning of resources, lack of protection of completed work, excessive overtime, and non-compliance with specification.

The analysis revealed that these factors had p-values $<0.05$, implying a significant difference in the professionals perception of these factors. The $p$-value of the remaining 15 rework risks triggers were observed to be greater than 0.05 , implying a non-significant difference in the opinion of the respondents. This finding is in disagreement with Simpeh (2012) and in agreement with Enshassi et al., (2017). 
INDEPENDENT JOURNAL OF MANAGEMENT \& PRODUCTION (IJM\&P)

http://www.ijmp.jor.br

v. 9, n. 2, April - June 2018

ISSN: 2236-269X

DOI: 10.14807/ijmp.v9i2.729

Simpeh (2012) reported a level of agreement among respondents for all the factors considered to be subcontractors-related contributors rework. Enshassi et al., (2017) reported $p$-value of 0.028 , which implies that, there is a level of disagreement among construction participants on contractors-related causes of rework in Palestine. The level of disagreement observed in this study could be attributed to the differences in what the professionals understands to be basic contractual requirements of a contract and the contractor.

The respondents maybe of the view that a contractor who cannot set-out a building line, should not take up construction job in the first place. Also, that there is no need being in construction business when a contract specification cannot be adequately followed. A clear project method statement should detail the requirements for protecting construction work.

Under the environmental-related causes, the result revealed that the p-values of one (1) out of the 6 risks factors assessed is less than 0.05 , which implies that there is a significant difference in the way these respondents from the different professions in the construction industry view this factor. This factor is damage due to weather conditions.

This difference in view could be attributed to the need to be sensitive to seasons or periods of the year in which construction activities can be smoothly be carried out without drawbacks. In Nigeria for instance, construction works are better during the dry season than in raining season. However, it is observed that there is a significant relationship in the perception of the respondents on other rework risks triggers under the environmental related causes, as their P-value $>0.05$.

Table 1: Comparation of Professionals Perception Regarding Rework Risks Triggers on building construction projects

\begin{tabular}{|c|c|c|c|c|c|c|}
\hline \multirow{2}{*}{ Factors } & \multicolumn{4}{|c|}{ Mean Rank } & \multirow{2}{*}{$\begin{array}{c}\text { P- } \\
\text { value }\end{array}$} & \multirow{2}{*}{ Decision } \\
\hline & Bldr. & Q.S & Arch. & Engr. & & \\
\hline \multicolumn{7}{|l|}{ Client-related factors } \\
\hline $\begin{array}{l}\text { Poor communication with the architect and } \\
\text { engineers (design consultants) }\end{array}$ & 93.22 & 102.57 & 88.60 & 90.74 & 0.5040 & Accept \\
\hline $\begin{array}{l}\text { Lack of knowledge and inexperience in project } \\
\text { design development }\end{array}$ & 98.48 & 97.53 & 86.95 & 94.88 & 0.7210 & Accept \\
\hline $\begin{array}{l}\text { Lack of knowledge and inexperience of the } \\
\text { construction process }\end{array}$ & 83.86 & 96.83 & 96.19 & 96.93 & 0.6540 & Accept \\
\hline $\begin{array}{l}\text { Inadequate time and money spent during } \\
\text { project brief development }\end{array}$ & 97.55 & 95.16 & 90.12 & 95.57 & 0.9290 & Accept \\
\hline Insufficient fund allocated to site investigations & 97.20 & 99.20 & 77.99 & 101.42 & 0.1190 & Accept \\
\hline $\begin{array}{l}\text { Lack of adequate participation of the client in } \\
\text { the project }\end{array}$ & 122.19 & 94.68 & 76.41 & 92.52 & $0.0030^{*}$ & Reject \\
\hline $\begin{array}{l}\text { Low fee payment for preparing contract } \\
\text { documents }\end{array}$ & 90.94 & 92.22 & 95.49 & 98.61 & 0.8980 & Accept \\
\hline
\end{tabular}


INDEPENDENT JOURNAL OF MANAGEMENT \& PRODUCTION (IJM\&P)

http://www.ijmp.jor.br

v. 9, n. 2, April - June 2018

ISSN: 2236-269X

DOI: 10.14807/ijmp.v9i2.729

\section{Design-related factors}

Changes requested by the client

Design not completed at tender time

$127.19 \quad 90.65$

$99.22 \quad 93.02$

80.73

90.48

$0.0010^{\star}$

Reject

Items omission from the contract documents

108.9191 .06

96.09

91.93

0.9210

Accept

Poor design coordination

Contractor initiated changes during

construction

$104.31 \quad 94.13$

100.82

84.13

0.1350

Accept

$95.78 \quad 97.96$

92.90

88.89

0.6280

Accept

Mistakes and Errors discovered in the contract documents

Inadequate time devoted for preparing contract

documents

$\begin{array}{llllll}100.16 & 93.24 & 101.66 & 86.28 & 0.4620 & \text { Accept }\end{array}$

Time boxing (i.e. fixed time for completing task)

insufficient client brief for preparing detailed

contract documents

Deficiency of required skills for completing task

Poor workload planning

Consultant's Ineffective use of quality

management practices

$97.27 \quad 93.25$

98.25

91.03

0.9030

Accept

$\begin{array}{llllll}76.28 & 100.52 & 98.80 & 95.02 & 0.1810 & \text { Accept }\end{array}$

Ineffective use of information technologies

$91.97 \quad 101.05$

92.31

90.15

0.6980

Accept

92.84

97.20

95.34

91.58

0.9440

Accept

77.83

102.82

94.85

94.71

0.1830

Accept

110.83

87.35

84.55

$101.39 \quad 0.0850$

Accept

\section{Contractor-related factors}

Errors in Setting out

Inadequate training and inexperience

Poor coordination of resources (e.g.

subcontractors)

Constructability problems

Contractor's Ineffective use of quality

management practices

Poor planning of resources

Lack of protection of completed work

Lack of safety

Excessive overtime

Non-compliance with specification

Low labour skill level

Shortage of skilled labour

Staff Turnover

Shortage of skilled supervisors

Defective workmanship

Inadequate Supervisor / Foreman /Tradesmen

ratios

$77.53 \quad 105.84$

$109.91 \quad 104.01$

$120.39 \quad 95.90$

97.58

93.15

0.0920

Accept

Damages to work due to carelessness

Unclear instruction to workers

87.9496 .62

87.61

70.80

$0.0010^{*}$

Reject

$83.16 \quad 107.07$

92.77

(2.52

$0.0090^{\star}$

Reject

87.59

97.57

0.8350

Accept

$101.59 \quad 92.04$

85.82

92.54

0.1090

Accept

$128.69 \quad 86.45$

$122.78 \quad 88.59$

$91.12 \quad 94.96$

87.62

100.48

0.4020

Accept

99.83

111.33

89.41

88.22

88.61

$0.0010^{\star}$

Reject

96.53

89.25

$0.0100^{\star}$

Reject

104.92

79.11

94.31

0.9780

Accept

97.39

93.40

94.18

110.52

$0.0230^{\star}$

Reject

87.97

92.57

99.09

71.75

$0.0010^{\star}$

Reject

88.00

100.81

90.04

0.8400

Accept

96.16

95.47

0.7440

Accept

$\begin{array}{lll}92.11 & 92.94 & 100.44\end{array}$

95.95

0.8920

Accept

100.12

99.24

84.88

92.74

0.8280

Accept

$85.83 \quad 100.20$

90.06

93.61

0.4760

Accept

$102.86 \quad 90.11$

97.93

96.95

0.5480

Accept

103.75

88.12

95.61

91.54

0.6650

Accept

88.45

97.41

94.65

95.36

0.5130

Accept

site conditions

incomplete and inaccurate information

$105.88 \quad 85.65$

86.62

98.29

98.67

94.69

0.8920

Accept

Machine breakdown or defects

94.11

94.35

0.1700

Accept

\section{Environmental-related causes}

Changes initiated by the municipality/regulatory bodies

Change in design due to economic changes

design change initiated due to social changes

design change initiated due to legal changes

Damage due to weather conditions

$\begin{array}{cccccc}83.25 & 90.88 & 90.94 & 108.96 & 0.1250 & \text { Accept } \\ 109.98 & 95.97 & 95.36 & 82.28 & 0.1370 & \text { Accept } \\ 99.95 & 98.66 & 97.65 & 83.39 & 0.3710 & \text { Accept } \\ 105.44 & 84.53 & 104.18 & 91.21 & 0.1500 & \text { Accept } \\ 115.73 & 90.61 & 99.61 & 81.41 & 0.0280^{\star} & \text { Reject } \\ 93.88 & 96.14 & 98.85 & 89.18 & 0.8250 & \text { Accept }\end{array}$

Damage due to natural disasters

Surveyor (Q.S), N = 44 for Architect (Arch.), N = 51 for

$\mathrm{N}=32$ for Building (Bldr.), $\mathrm{N}=61$ for Quantity Surveyor (Q.S), $\mathrm{N}$
Engineering (Engr.), $\mathrm{df}=3$

$$
\text { Engineering (Engr.), } \mathrm{df}=3
$$




\subsection{Rework Risks Triggers on building construction projects}

Table 2 shows the result of the analysis and ranks of the respondents' response on the extent to which the identified rework triggers contribute to rework occurrences in the construction industry; using the 5-points Likert scale below, where $1=$ very Low, 2 = Low, $3=$ Average, $4=$ High, $5=$ very High .

Under client-related category; the Builders are of the opined that the top four factors that triggers the emergence of rework are Poor communication with the architect and engineers (design consultants) ranked $1^{\text {st }}$, Inadequate time and money spent during project brief development ranked $2^{\text {nd }}$, Lack of knowledge and inexperience in project design development, and Insufficient fund allocated to site investigations which ranked $3^{\text {rd }}$ each.

The Quantity surveyors ranked Poor communication with the architect and engineers (design consultants) as $1^{\text {st }}$, Lack of knowledge and inexperience in project design development as $2^{\text {nd }}$, Inadequate time and money spent during project brief development, and Insufficient fund allocated to site investigations were each ranked $3^{\text {rd }}$.

According to the Architects, the top factors that trigger rework are Poor communication with the architect and engineers (design consultants), Lack of knowledge and inexperience of the construction process, Low fee payment for preparing contract documents, Lack of knowledge and inexperience in project design development which ranked $1^{\text {st }}, 2^{\text {nd }}, 3^{\text {rd }}$ and $4^{\text {th }}$ respectively.

The engineers ranked Insufficient fund allocated to site investigations $1^{\text {st }}$, Lack of knowledge and inexperience in project design development, and Inadequate time and money spent during project brief development were each ranked $2^{\text {nd }}$ and Poor communication with the architect and engineers (design consultants) was ranked $4^{\text {th }}$.

On the overall, the top rework triggers that are related to the client are Poor communication with the architect and engineers (design consultants), Inadequate time and money spent during project brief development, Lack of knowledge and inexperience in project design development, and Insufficient fund allocated to site investigations which ranked $1^{\text {st }}, 2^{\text {nd }}, 3^{\text {rd }}$, and $4^{\text {th }}$ respectively.

This result corroborates the findings of (MAHAMID, 2016; ENSHASSi et al., 2017; PALANEESWARAN, 2006). Mahamid (2016) reported that poor 
INDEPENDENT JOURNAL OF MANAGEMENT \& PRODUCTION (IJM\&P)

http://www.ijmp.jor.br

v. 9, n. 2, April - June 2018

ISSN: 2236-269X

DOI: 10.14807/ijmp.v9i2.729

communication with the contract, poor communication with the design consultant, lack of client involvement in the project and lack of funding allocated for site investigation; are factors with high severity index that may lead to late materials and specifications changes during the project's construction phase that could result to rework.

Palaneeswaran (2006) specified that the main causes of owner related rework are lack of knowledge of design and construction process, insufficient fund allocated for site investigation, lack of client involvement throughout the project, inadequate briefing, poor communication with design consultants; and inadequacies in contract documentation.

Enshassi et al., (2017) found out that inadequate briefing, lack of knowledge of construction process, lack of funding allocated for site investigation, change due to change of officials, and lack of funding allocated for consultation; are the major owner causes of rework that impact on the time and cost of construction projects. Therefore, Simpeh (2012) observed that these client-related factors are significant correlated to the impact of rework on project performance.

For the design-related category; the Builders are of the opined that the top five factors that triggers the emergence of rework are Items omission from the contract documents ranked $1^{\text {st }}$, Changes requested by the client ranked $2^{\text {nd }}$, Mistakes and Errors discovered in the contract documents ranked $3^{\text {rd }}$, Design not completed at tender time, Poor design coordination and Deficiency of required skills for completing task ranked $4^{\text {th }}$ each.

The Quantity surveyors ranked Deficiency of required skills for completing task, Design not completed at tender time, Items omission from the contract documents, Mistakes and Errors discovered in the contract documents, and Contractor initiated changes during construction as $1^{\text {st }}, 2^{\text {nd }}, 3^{\text {rd }}, 4^{\text {th }}$ and $5^{\text {th }}$ respectively.

According to the Architects, the top five factors that trigger rework are Items omission from the contract documents, and Mistakes and Errors discovered in the contract documents each ranked $1^{\text {st }}$, Deficiency of required skills for completing task, Design not completed at tender time and Poor design coordination which ranked $3^{\text {rd, }}$ $4^{\text {th }}$ and $5^{\text {th }}$ respectively.

The engineers ranked Deficiency of required skills for completing task, Design not completed at tender time, Items omission from the contract documents, Mistakes 
and Errors discovered in the contract documents, and Poor design coordination as $1^{\text {st }}, 2^{\text {nd }}, 3^{\text {rd }}, 4^{\text {th }}$ and $5^{\text {th }}$ respectively.

While on the overall, the top five factors that are related to design that triggers rework are Items omission from the contract documents, Deficiency of required skills for completing task, Design not completed at tender time, Mistakes and Errors discovered in the contract documents, and Poor design coordination which ranked $1^{\text {st }}, 2^{\text {nd }}, 3^{\text {rd }}, 4^{\text {th }}$ and $5^{\text {th }}$ respectively. This result is consistent with the findings of (SIMPEH, 2012; MAHAMID 2016; ENSHASSI et al., 2017).

Simpeh (2012) found out that the most prominent source of design induced rework are changes made at the request of the client, incomplete design at the time of tender, and omission of items from the contract documents. Enshassi et al. (2017) reported that design errors and omission, incomplete information for design, incomplete design, and lack of professionalism are major factors related to design that have high impact on project performance.

According to Mahamid (2016), late design changes, errors and omissions and lack of designers' experience are the top three causes of rework related to design consultants. These factors have a very wide impact on project performance (MAHAMID 2017; ENSHASSI et al. 2017; JOSEPHSON et al., 2002). This result is also in agreement with (LOVE et al., 1999; JOSEPHSON et al., 2002).

Love et al., (1999) stressed that insufficiently advanced contract documents is a consequent of inadequate information and limited time allocated to design related activities which may lead to rework. Love et al. (1999) further stated that the focus of solving site problems due to design errors inversely influences productivity, performance and production cost, whilst rework impact directly on production cost.

Josephson et al. (2002) are of the opinion that design causes that are capable of causing rework are incomplete designs, inadequate information for design, and lack of professionalism. Oyewobi and Ogunsemi (2010) advocated the need for unity among all stakeholders so that the design process will be properly coordinated and workable plan put in place to prevent rework emergence.

For the contractor-related category; the Builders are of the opined that the top five factors that triggers the emergence of rework are incomplete and inaccurate information, Unclear instruction to workers, Errors in Setting out, Shortage of skilled supervisors, and Non-compliance with specification which ranked $1^{\text {st }}, 2^{\text {nd }}, 3^{\text {rd }}, 4^{\text {th }}$ and $5^{\text {th }}$ respectively. 
INDEPENDENT JOURNAL OF MANAGEMENT \& PRODUCTION (IJM\&P)

http://www.ijmp.jor.br

v. 9, n. 2, April - June 2018

ISSN: 2236-269X

DOI: 10.14807/ijmp.v9i2.729

The Quantity surveyors ranked Shortage of skilled supervisors, Errors in Setting out, Unclear instruction to workers as $1^{\text {st }}, 2^{\text {nd }}$ and $3^{\text {rd }}$ respectively, and Constructability problems, and Non-compliance with specification occupied $4^{\text {th }}$ position each.

According to the Architects, the top five factors that trigger rework are Shortage of skilled supervisors, Unclear instruction to workers, incomplete and inaccurate information, Errors in Setting out, and Non-compliance with specification which ranked $1^{\text {st }}, 2^{\text {nd }}, 3^{\text {rd }}, 4^{\text {th }}$ and $5^{\text {th }}$ respectively. The engineers ranked Unclear instruction to workers, Shortage of skilled supervisors, Contractor's Ineffective use of quality management practices, incomplete and inaccurate information, and Excessive overtime as $1^{\text {st }}, 2^{\text {nd }}, 3^{\text {rd }}, 4^{\text {th }}$ and $5^{\text {th }}$ respectively.

The overall ranking of the top five contractors-related factors that triggers rework are Unclear instruction to workers, Shortage of skilled supervisors, incomplete and inaccurate information, Errors in Setting out, and Contractor's Ineffective use of quality management practices which ranked $1^{\text {st }}, 2^{\text {nd }}, 3^{\text {rd }}, 4^{\text {th }}$ and $5^{\text {th }}$ respectively. This report is supported by (ENSHASSI et al., 2017; MAHAMID, 2016; SIMPEH, 2012).

Mahamid (2016) reported that the top six contractor related causes of rework are Poor communication with the consultant, Use of poor quality material, Poor site management, Improper subcontractor selection, Use of inefficient equipment, and Ineffective use of quality control system. Causes under the contractors groups have wide severity index and their impact ranges from moderate to high.

Enshassi et al. (2017) concluded that poor quality system by the contract With RII of $78.2 \%$, result to rework and has a considerable impact on project cost and time. Simpeh (2012) stated that setting out errors, lack of training and experience, poor coordination of subcontractors, non-compliance with specification by the subcontractors, low labour skill level and shortage of skilled labour are the major factors responsible for rework under site management factors and subcontractorrelated factors.

It is clear that the management and coordination of the site and subcontractors are the responsibility of the main contractors. Oyewobi and Ogunsemi (2010) made an assertion which implies that buildings can be constructed free of rework when there is adequate and non-conflicting information. 
INDEPENDENT JOURNAL OF MANAGEMENT \& PRODUCTION (IJM\&P)

http://www.ijmp.jor.br

v. 9, n. 2, April - June 2018

ISSN: 2236-269X

DOI: 10.14807/ijmp.v9i2.729

Under the environmental-related category, the Builders are of the opined that the top three factors that triggers the emergence of rework are Damage due to weather conditions, Change in design due to economic changes, and design change initiated due to social changes which ranked $1^{\text {st }}, 2^{\text {nd }}$ and $3^{\text {rd }}$ respectively.

The Quantity surveyors ranked Change in design due to economic changes, design change initiated due to social changes, and Damage due to weather conditions as $1^{\text {st }}, 2^{\text {nd }}$, and $3^{\text {rd }}$ respectively. According to the Architects, the top three factors that trigger rework Damage due to weather conditions, Change in design due to economic changes, and Damage due to natural disasters, which ranked $1^{\text {st }}, 2^{\text {nd }}$ and $3^{\text {rd }}$ respectively.

The engineers ranked Changes initiated by the municipality/regulatory bodies, Damage due to weather conditions, and Damage due to natural disasters as $1^{\text {st }}, 2^{\text {nd }}$ and 3rd respectively.

While on the overall, the top three factors that are related to Damage due to weather conditions, Change in design due to economic changes, and Changes initiated by the municipality/regulatory bodies, which ranked $1^{\text {st }}, 2^{\text {nd }}$, and $3^{\text {rd }}$ respectively. This result is supported by (ENSHASSI et al., 2017; MAHAMID, 2016; MASTENBROEK, 2010).

Enshassi et al. (2017) found out that political situation, economy (i.e. exchange rate, inflation, market condition), and physical infrastructures are the critical environmental factors that influence the occurrence of rework. Mahami (2016) reported that causes with high severity index that are related to external environmental factors are weather and lack of safety. External environmental factors are factors beyond the control of project participants (MOHAMED, 2015; OMRAN et al., 2012).

According to Omran et al., (2012), the three external environment factors that influence construction projects performance are economic environment factors, political environment, and social environment, which were ranked $1^{\text {st }}, 2^{\text {nd }}$ and $3^{\text {rd }}$ respectively. Mahami (2016) argue that environmental factors have low to moderate impact on project performance. Construction rework could result from weather conditions, disasters from natural forces, or changes in external environment (MASTENBROEK, 2010). 
INDEPENDENT JOURNAL OF MANAGEMENT \& PRODUCTION (IJM\&P)

http://www.ijmp.jor.br

v. 9, n. 2, April - June 2018

ISSN: 2236-269X

DOI: 10.14807/ijmp.v9i2.729

Table 2: Rework Risks Triggers on Building Construction Projects

\begin{tabular}{|c|c|c|c|c|c|c|c|c|c|c|}
\hline \multirow[b]{2}{*}{ Factors } & \multicolumn{2}{|c|}{ Bldr } & \multicolumn{2}{|c|}{ Q. S } & \multicolumn{2}{|c|}{ Arch. } & \multicolumn{2}{|c|}{ Engr } & \multicolumn{2}{|c|}{ Overall } \\
\hline & MIS & $\begin{array}{c}\text { Rk } \\
.\end{array}$ & MIS & $\begin{array}{c}\mathbf{R k} \\
.\end{array}$ & MIS & $\begin{array}{c}\mathbf{R k} \\
.\end{array}$ & MIS & $\begin{array}{c}\mathbf{R k} \\
.\end{array}$ & MIS & $\begin{array}{l}\mathbf{R} \\
\mathbf{k} .\end{array}$ \\
\hline \multicolumn{11}{|l|}{ Client-related factors } \\
\hline $\begin{array}{l}\text { Poor communication with the architect and } \\
\text { engineers (design consultants) }\end{array}$ & 3.91 & 1 & 4.00 & 1 & 3.91 & 1 & 3.88 & 4 & 3.92 & 1 \\
\hline $\begin{array}{l}\text { Lack of knowledge and inexperience in project } \\
\text { design development }\end{array}$ & 3.81 & 3 & 3.89 & 2 & 3.73 & 4 & 3.92 & 2 & 3.83 & 3 \\
\hline $\begin{array}{l}\text { Lack of knowledge and inexperience of the } \\
\text { construction process }\end{array}$ & 3.44 & 7 & 3.75 & 5 & 3.84 & 2 & 3.86 & 5 & 3.72 & 5 \\
\hline $\begin{array}{l}\text { Inadequate time and money spent during project } \\
\text { brief development }\end{array}$ & 3.88 & 2 & 3.85 & 3 & 3.71 & 5 & 3.92 & 2 & 3.84 & 2 \\
\hline Insufficient fund allocated to site investigations & 3.81 & 3 & 3.85 & 3 & 3.32 & 6 & 3.96 & 1 & 3.74 & 4 \\
\hline $\begin{array}{l}\text { Lack of adequate participation of the client in the } \\
\text { project }\end{array}$ & 3.72 & 5 & 3.03 & 7 & 2.61 & 7 & 3.00 & 7 & 3.09 & 7 \\
\hline $\begin{array}{l}\text { Low fee payment for preparing contract } \\
\text { documents }\end{array}$ & 3.56 & 6 & 3.64 & 6 & 3.75 & 3 & 3.82 & 6 & 3.69 & 6 \\
\hline \multicolumn{11}{|l|}{ Design-related factors } \\
\hline Changes requested by the client & 4.28 & 2 & 3.48 & 10 & 3.27 & 10 & 3.49 & 10 & 3.63 & 9 \\
\hline Design not completed at tender time & 4.03 & 4 & 4.03 & 2 & 4.07 & 4 & 4.00 & 2 & 4.03 & 3 \\
\hline Items omission from the contract documents & 4.31 & 1 & 4.02 & 3 & 4.16 & 1 & 3.90 & 3 & 4.10 & 1 \\
\hline Poor design coordination & 4.03 & 4 & 3.84 & 8 & 3.86 & 5 & 3.78 & 5 & 3.88 & 5 \\
\hline Contractor initiated changes during construction & 3.84 & 8 & 3.97 & 5 & 3.75 & 6 & 3.73 & 7 & 3.82 & 6 \\
\hline $\begin{array}{l}\text { Mistakes and Errors discovered in the contract } \\
\text { documents }\end{array}$ & 4.09 & 3 & 3.98 & 4 & 4.16 & 1 & 3.86 & 4 & 4.02 & 4 \\
\hline $\begin{array}{l}\text { Inadequate time devoted for preparing contract } \\
\text { documents }\end{array}$ & 3.44 & 9 & 3.49 & 9 & 3.61 & 9 & 3.45 & 11 & 3.50 & 11 \\
\hline Time boxing (i.e. fixed time for completing task) & 2.56 & 13 & 3.31 & 12 & 3.25 & 12 & 3.14 & 12 & 3.07 & 13 \\
\hline $\begin{array}{l}\text { insufficient client brief for preparing detailed } \\
\text { contract documents }\end{array}$ & 3.00 & 12 & 3.31 & 12 & 3.07 & 13 & 3.00 & 13 & 3.09 & 12 \\
\hline Deficiency of required skills for completing task & 4.03 & 4 & 4.15 & 1 & 4.11 & 3 & 4.06 & 1 & 4.09 & 2 \\
\hline Poor workload planning & 3.34 & 10 & 3.87 & 7 & 3.73 & 7 & 3.73 & 7 & 3.67 & 7 \\
\hline $\begin{array}{l}\text { Consultant's Ineffective use of quality } \\
\text { management practices }\end{array}$ & 4.00 & 7 & 3.33 & 11 & 3.27 & 10 & 3.75 & 6 & 3.59 & 10 \\
\hline Ineffective use of information technologies & 3.31 & 11 & 3.89 & 6 & 3.66 & 8 & 3.67 & 9 & 3.63 & 8 \\
\hline \multicolumn{11}{|l|}{ Contractor-related factors } \\
\hline Errors in Setting out & 4.47 & 3 & 4.39 & 2 & 4.27 & 4 & 3.76 & 10 & 4.22 & 4 \\
\hline Inadequate training and inexperience & 3.41 & 18 & 3.02 & 21 & 2.80 & 21 & 2.73 & 21 & 2.99 & 21 \\
\hline $\begin{array}{l}\text { Poor coordination of resources (e.g. } \\
\text { subcontractors) }\end{array}$ & 3.94 & 10 & 4.07 & 10 & 4.00 & 6 & 4.08 & 8 & 4.02 & 9 \\
\hline Constructability problems & 3.81 & 12 & 4.28 & 4 & 3.91 & 10 & 4.00 & 9 & 4.00 & 10 \\
\hline $\begin{array}{l}\text { Contractor's Ineffective use of quality } \\
\text { management practices }\end{array}$ & 4.22 & 7 & 4.18 & 7 & 3.98 & 8 & 4.31 & 3 & 4.17 & 5 \\
\hline Poor planning of resources & 4.09 & 9 & 3.23 & 18 & 3.25 & 19 & 3.27 & 18 & 3.46 & 17 \\
\hline Lack of protection of completed work & 4.19 & 8 & 3.52 & 14 & 3.50 & 15 & 3.53 & 15 & 3.69 & 12 \\
\hline Lack of safety & 2.94 & 21 & 3.03 & 20 & 3.07 & 20 & 3.02 & 20 & 3.01 & 20 \\
\hline Excessive overtime & 3.78 & 13 & 3.51 & 16 & 3.45 & 16 & 4.18 & 5 & 3.73 & 11 \\
\hline Non-compliance with specification & 4.28 & 5 & 4.28 & 4 & 4.07 & 5 & 3.61 & 13 & 4.06 & 7 \\
\hline Low labour skill level & 3.59 & 14 & 3.52 & 14 & 3.64 & 12 & 3.45 & 16 & 3.55 & 15 \\
\hline Shortage of skilled labour & 3.47 & 16 & 3.54 & 13 & 3.75 & 11 & 3.63 & 12 & 3.60 & 14 \\
\hline Staff Turnover & 3.41 & 18 & 3.59 & 12 & 3.59 & 14 & 3.59 & 14 & 3.54 & 16 \\
\hline Shortage of skilled supervisors & 4.31 & 4 & 4.41 & 1 & 4.50 & 1 & 4.39 & 2 & 4.40 & 2 \\
\hline Defective workmanship & 4.25 & 6 & 4.21 & 6 & 3.98 & 8 & 4.12 & 6 & 4.14 & 6 \\
\hline $\begin{array}{l}\text { Inadequate Supervisor / Foreman /Tradesmen } \\
\text { ratios }\end{array}$ & 3.91 & 11 & 4.16 & 8 & 4.00 & 6 & 4.12 & 6 & 4.05 & 8 \\
\hline Damages to work due to carelessness & 3.47 & 16 & 3.18 & 19 & 3.36 & 18 & 3.22 & 19 & 3.31 & 19 \\
\hline Unclear instruction to workers & 4.59 & 2 & 4.31 & 3 & 4.45 & 2 & 4.45 & 1 & 4.45 & 1 \\
\hline $\begin{array}{l}\text { change in construction methods cause by } \\
\text { site conditions }\end{array}$ & 3.50 & 15 & 3.70 & 11 & 3.64 & 12 & 3.65 & 11 & 3.62 & 13 \\
\hline incomplete and inaccurate information & 4.63 & 1 & 4.10 & 9 & 4.41 & 3 & 4.29 & 4 & 4.36 & 3 \\
\hline
\end{tabular}


INDEPENDENT JOURNAL OF MANAGEMENT \& PRODUCTION (IJM\&P)

http://www.ijmp.jor.br

v. 9, n. 2, April - June 2018

ISSN: 2236-269X

DOI: 10.14807/ijmp.v9i2.729

\begin{tabular}{lllllllllll} 
Machine breakdown or defects & 3.28 & 20 & 3.51 & 16 & 3.43 & 17 & 3.45 & 16 & 3.42 & 18 \\
\hline $\begin{array}{l}\text { Environmental-related causes } \\
\text { Changes initiated by the municipality/regulatory }\end{array}$ & 2.84 & 6 & 3.10 & 4 & 3.09 & 5 & 3.53 & 1 & 3.14 & 3 \\
bodies & 3.59 & 2 & 3.26 & 1 & 3.25 & 2 & 2.96 & 4 & 3.27 & 2 \\
Change in design due to economic changes & 3.22 & 3 & 3.21 & 2 & 3.16 & 4 & 2.86 & 5 & 3.11 & 4 \\
design change initiated due to social changes & 3.00 & 5 & 2.57 & 6 & 2.98 & 6 & 2.71 & 6 & 2.81 & 6 \\
design change initiated due to legal changes & 3.75 & 1 & 3.20 & 3 & 3.39 & 1 & 3.00 & 2 & 3.33 & 1 \\
Damage due to weather conditions & 3.06 & 4 & 3.10 & 4 & 3.23 & 3 & 2.98 & 3 & 3.09 & 5 \\
Damage due to natural disasters & & & & & & & & & \\
\hline
\end{tabular}

Bldr. = Builder; Q. S = Quantity Surveyor; Arch. = Architect; Engr. Engineer; Rk = Rank

\subsection{Category of Rework Risks Triggers}

Table 3 shows the major categories of rework risks factors. According to the results, rework risks triggers that are related to the contractor was ranked first in the group with overall (MIS=3.80), implying that the contractors are responsible for majority of the rework incidences in construction projects.

This finding is supported by statement of Enshassi et al. (2017), which implied that contractors are the highest contributor to rework occurrence and their activities have high impact on project overall performance. This result corroborates the findings of (LOVE; EDWARDS, 2004a; LOVE et al., 1999; PALANEESWARAN, 2006; SIMPEH, 2012).

Rework risk factors related to design factors was ranked second in the group with (MIS = 3.70), implying second highest cause of rework and high impact on project success. Client-related factors that trigger the occurrence of rework was ranked third with (MIS = 3.69) and the Environmental-related causes was ranked forth with (MIS=3.13).

This result is supported by (MAHAMID, 2016; LOVE et al., 1999; PALANEESWARAN, 2006; ENSHASSI et al., 2017; SIMPEH, 2012). Since, each of the group have their MIS $>3.0$, it means that their activities either at design or construction stage have significant impact on the emergence of rework.

Table 3: Category of Rework Risks Triggers

\begin{tabular}{clcccccc}
\hline \multirow{2}{*}{ S/No } & \multirow{2}{*}{$\begin{array}{l}\text { Category of Rework Risks } \\
\text { Triggers }\end{array}$} & \multicolumn{4}{c}{ Average MIS } & \multirow{2}{*}{ Overall } & Rank \\
\cline { 3 - 5 } & Bldr. & Q. S & Arch. & Engr. & & 3 \\
2 & Client-related factors & 3.73 & 3.72 & 3.56 & 3.77 & 3.69 & 3.70 \\
2 & Design-related factors & 3.71 & 3.74 & 3.69 & 3.66 & 3.70 & 1 \\
3 & Contractor-related factors & 3.88 & 3.80 & 3.76 & 3.75 & 3.80 & 4 \\
4 & Environmental-related cause & 3.24 & 3.07 & 3.18 & 3.01 & 3.13 & 4 \\
\hline
\end{tabular}

Bldr. = Builder; Q. S = Quantity Surveyor; Arch. = Architect; Engr. Engineer; Rk = Rank 
INDEPENDENT JOURNAL OF MANAGEMENT \& PRODUCTION (IJM\&P)

http://www.ijmp.jor.br

v. 9, n. 2, April - June 2018

ISSN: 2236-269X

DOI: 10.14807/ijmp.v9i2.729

\subsection{Fifteen most important rework risks triggers on building construction projects}

Table 4 displays a summary of the top fifteen (15) rework risks triggers from the overall rework triggers on Table 2. From the overall rank on column 11, rework factors that are ranked from $1^{\text {st }}-5^{\text {th }}$ are related to the activities of the contractors.

From factors on $6^{\text {th }}$ to $9^{\text {th }}$ are design-related factors, which are the major responsibilities of the consultants, and the $10^{\text {th }}$ factor is related to the client. The two last factors, $14^{\text {th }}-15^{\text {th }}$ are related to the external environment of the project.

It is evident that the majority of the top fifteen rework triggers emerges from the activities, weaknesses and inefficiencies of the contractor. This finding further supported the result on Table 3, and the reports of previous researchers (AJAYl; OYEYIPO, 2015; ENSHASSI et al., 2017; LOVE; EDWARDS, 2004a; LOVE et al.,1999; MAHAMID, 2016; PALANEESWARAN, 2006; SIMPEH, 2012).

Table 4: Top Fifteen (15) Rework Risks Triggers on building construction projects

\begin{tabular}{|c|c|c|c|c|c|c|c|c|c|c|}
\hline \multirow{2}{*}{ Factors } & \multicolumn{2}{|c|}{ Bldr } & \multicolumn{2}{|c|}{ Q. S } & \multicolumn{2}{|c|}{ Arch. } & \multicolumn{2}{|c|}{ Engr } & \multicolumn{2}{|c|}{ Overall } \\
\hline & MIS & Rk. & MIS & Rk. & MIS & Rk. & MIS & Rk. & MIS & $\mathbf{R k}$ \\
\hline $\begin{array}{l}\text { Poor communication with the architect and } \\
\text { engineers (design consultants) }\end{array}$ & 3.91 & 11 & 4.00 & 9 & 3.91 & 10 & 3.88 & 10 & 3.92 & 10 \\
\hline $\begin{array}{l}\text { Lack of knowledge and inexperience in } \\
\text { project design development }\end{array}$ & 3.81 & 13 & 3.89 & 11 & 3.73 & 12 & 3.92 & 7 & 3.83 & 13 \\
\hline $\begin{array}{l}\text { Inadequate time and money spent during } \\
\text { project brief development }\end{array}$ & 3.88 & 12 & 3.85 & 12 & 3.71 & 13 & 3.92 & 7 & 3.84 & 12 \\
\hline Design not completed at tender time & 4.03 & 8 & 4.03 & 7 & 4.07 & 8 & 4.00 & 6 & 4.03 & 8 \\
\hline Items omission from the contract documents & 4.31 & 4 & 4.02 & 8 & 4.16 & 5 & 3.90 & 9 & 4.10 & 6 \\
\hline Poor design coordination & 4.03 & 8 & 3.84 & 13 & 3.86 & 11 & 3.78 & 12 & 3.88 & 11 \\
\hline $\begin{array}{l}\text { Mistakes and Errors discovered in the } \\
\text { contract documents }\end{array}$ & 4.09 & 7 & 3.98 & 10 & 4.16 & 5 & 3.86 & 11 & 4.02 & 9 \\
\hline Deficiency of required skills for completing task & 4.03 & 8 & 4.15 & 5 & 4.11 & 7 & 4.06 & 5 & 4.09 & 7 \\
\hline Errors in Setting out & 4.47 & 3 & 4.39 & 2 & 4.27 & 4 & 3.76 & 13 & 4.22 & 4 \\
\hline $\begin{array}{l}\text { Contractor's Ineffective use of quality } \\
\text { management practices }\end{array}$ & 4.22 & 6 & 4.18 & 4 & 3.98 & 9 & 4.31 & 3 & 4.17 & 5 \\
\hline Shortage of skilled supervisors & 4.31 & 4 & 4.41 & 1 & 4.50 & 1 & 4.39 & 2 & 4.40 & 2 \\
\hline Unclear instruction to workers & 4.59 & 2 & 4.31 & 3 & 4.45 & 2 & 4.45 & 1 & 4.45 & 1 \\
\hline incomplete and inaccurate information & 4.63 & 1 & 4.10 & 6 & 4.41 & 3 & 4.29 & 4 & 4.36 & 3 \\
\hline Change in design due to economic changes & 3.59 & 15 & 3.26 & 14 & 3.25 & 15 & 2.96 & 15 & 3.27 & 15 \\
\hline Damage due to weather conditions & 3.75 & 14 & 3.20 & 15 & 3.39 & 14 & 3.00 & 14 & 3.33 & 14 \\
\hline
\end{tabular}

Bldr. = Builder; Q. S = Quantity Surveyor; Arch. = Architect; Engr. Engineer; Rk = Rank

\section{CONCLUSION AND RECOMMENDATIONS}

Based on the findings, it was concluded that rework factors related to the contractor's activities and those related to the activities of the design consultants are 
INDEPENDENT JOURNAL OF MANAGEMENT \& PRODUCTION (IJM\&P)

http://www.ijmp.jor.br

v. 9, n. 2, April - June 2018

ISSN: 2236-269X

DOI: 10.14807/ijmp.v9i2.729

the major categories of rework risks triggers. Furthermore, it was concluded that unclear instruction to workers, Shortage of skilled supervisors, incomplete and inaccurate information, Errors in Setting out, and Contractor's Ineffective use of quality management practices are the main triggers of rework in the construction industry.

In addition, built environment professionals views varies significantly on causes such as Lack of adequate participation of the client in the project, Changes requested by the client, Errors in Setting out, Inadequate training and inexperience, Poor planning of resources, Lack of protection of completed work, Excessive overtime, Non-compliance with specification, and Damage due to weather conditions.

Based on the conclusion, the study therefore, recommends the need for clarity, effectiveness and timeliness of instruction and information among project participants. In addition, the use of skilled and experienced professionals, skilled supervisors and proper implementation of quality management practices by both the design consultant and contractor throughout the project's phases, is necessary if rework free construction is to be achieved.

\section{REFERENCES}

ABDUL-RAHMAN, I.; MEMON, A. H.; ABD-KARIM, A. T. (2013) Significant factors causing cost overruns in large construction projects in Malaysia. Journal of Applied Sciences, v. 13, n. 2, p. 286-293. Available: http:// http://docsdrive.com/pdfs/ansinet/jas/2013/286-293.pdf. Access: $7^{\text {th }}$ July, 2016. DOI: 10.3923/jas.2013.286.293

AJAYI, O.; OYEYIPO, O. (2015) Effect of rework on project performance in building project in Nigeria. International Journal of Engineering Research \& Technology (IJERT), v. 4, n. 2, p. 294-300.

ALRECK, P. L.; SETTLE, R. B. (1985) "The survey research handbook." Richard D. Irwin, Inc., Homewood, III.

ANIL, A.; DANIELRAJ, R. C. (2016) Analyze the causes and minimize the occurrence of rework in construction project. International Journal of Innovative Research In Science, Engineering \& Technology, v. 5, n. 4, p. 6464-6467.

Available : https://www.ijirset.com/upload/2016/april/253_MY\%20JOURNAL_M.pdf. Access : 5/01/2017. Doi:10.156 80/ljirset.2016.0504253

BARBER, P.; GRAVES, A.; HALL, M.; SHEATH, D.; TOMKINS, C. (2000) Quality failure costs in civil engineering projects. International Journal of Quality and Reliability Management, v. 17, n. 4/5, p. 479-492. 
INDEPENDENT JOURNAL OF MANAGEMENT \& PRODUCTION (IJM\&P)

http://www.ijmp.jor.br

v. 9, n. 2, April - June 2018

ISSN: 2236-269X

DOI: 10.14807/ijmp.v9i2.729

CUSACK, D. (1992) Implementation of ISO 9000 in construction. ISO 9000 Forum Symposium, the International Group for Lean Construction. Gold Coast, Australia, p.157-167.

DALTY, C. D.; CRAWSHAW, D. T. (1973) Working Drawings in Use, Building Research Establishment, Current Paper CP 18/73, Watford, UK.

DAVIS, K.; LEDBETTER, W. B.; BURATTI, J. L. (1989) Measuring design and construction quality costs. ASCE Journal of Construction Engineering and Management, v. 115, n. 3, p. 389-400.

ENSHASSI, A.; SUNDERMEIER, M.; ZEITER, M. A. (2017) Factors Contributing to Rework and their Impact on Construction Projects Performance. International Journal of Sustainable Construction Engineering \& Technology, v. 8, n. 1, p. 12-33.

FANIRAN, O. O.; LOVE, P. E. D.; LI, H. (1999), Optimal allocation of construction planning resources. ASCE Journal of Construction Engineering and Management, v. 125, n. 5, p. 311-319.

FELLOWS, R. R.; LIU, A. (2008) Research Methods for Construction, 3rd Edition. Wiley- Blackwell Science, London.

GHASEMI, A.; ZAHEDIASL, S. (2012) Normality Test for Statistical Analys is: A guide for non- statisticians. International Journal of EndocrinolMetab, v.10, n. 2, p. 486-489.

HWANG, B. G.; THOMAS, S. R.; HAAS, C. T.; CALDAS, C. H. (2009) Measuring the Impact of Rework on Construction Cost Performance. Journal of Construction Engineering and Management, v. 135, n. 3, p. 187-198.

IRELAND, V. (1985) The role of managerial actions in the cost, time and quality performance of high rise commercial projects. Construction Management and Economics, v. 3, n. 1, p. 59-87.

JOSEPHSON, P. E.; HAMMARLUND, Y. (1999) The causes and costs of defects in construction: A study of seven building projects. Automation in Construction, v. 8, n. 6, p. 681-687.

JOSEPHSON, P.; LARSSON, B.; LI, H. (2002) Illustrative benchmarking rework and rework costs in Swedish construction industry. Journal of Management Engineering, v. 18, n. 2, p. 76-83.

KREJCIE, R. V.; MORGAN, D. W. (1970) Determining Sample Size for Research Activities. Educational and Psychological Measurement, v. 30, p. 607-610.

LOVE, P. E. D. (2002a) Influence of project type and procurement Method of Rework Costs in Building Construction Projects. Journal of Construction Engineering and Management, v. 128, n. 1, p. 1-29.

LOVE, P. E. D. (2002b) Auditing the indirect consequences of rework in construction: a case based approach. Managerial Auditing Journal, v. 17, n. 3, p.138-146.

LOVE, P. E. D.; LI, H. (2000) Quantifying the causes and costs of rework in construction. Construction Management and Economics, v. 18, n. 4, p. 479-490.

LOVE, P. E. D.; MANDAL, P.; LI, H. (1999a) Determining the causal structure of rework in construction projects. Construction Management and Economics, v. 17, n. 4, p. 505-517. 
LOVE, P. E. D.; EDWARDS, D. (2004a) Determinants of Rework in Building Construction Projects. Engineering, Construction and Architectural Management, v. 11, n. 4, p.259 -274.

LOVE, P. E. D.; SMITH, J. (2003) Benchmarking, bench-action and bench-learning: rework mitigation in projects. ASCE Journal of Management in Engineering, v. 19, n. 4 , p. 147-159.

LOVE, P. E. D.; DAVIS, P. R.; ELLIS, J. M.; CHEUNG, S. O. (2010) Dispute causation: Identification of Pathogenic Influences. Engineering, Construction and Architectural Management, v. 17, n. 4, p. 404-423.

LOVE, P. E. D.; HOLT, G. D.; SHEN, L. Y.; LI, H.; IRANI, Z. (2002) Using systems dynamics to better understand change and rework in construction project,

management systems. International Journal of Project Management, v. 20, n. 6, p. 425-436.

MAHAMID, I. (2016) Analysis of Rework in Residential Building Projects in Palestine. Jordan Journal of Civil Engineering, v. 10, n. 2, p. 197-208.

MAROSSZEKY, M. (2006) Performance Measurement and Visual Feedback for Process Improvement. A Special Invited Lecture presented in the SMILE-SMC 3rd Dissemination Workshop. Centre for Infrastructure and Construction Industry Development of the University of Hong Kong, Hong Kong, 2006.

MASTENBROEK, Y. C. (2010) Reducing rework costs in construction projects. Published Bsc thesis, University of Twente, San Pedro Sula, Honduras. Available: http://purl.utwente.nl/essays/59691. Access: 10/12/2016.

MESHKSAR, S. (2012) Cost And Time Impacts Of Reworks In Building A Reinforced Concrete Structure. Master Thesis. North Cyprus, Gazimagusa: Eastern Mediterranean University. Available: http://hdl.handle.net/11129/290. Access: 10/12/2016.

MOHAMED, M. B. I. (2015) A Study Of Project Delay In Sudan Construction Industry. Published Msc thesis, Universiti Tunku Abdul Rahman. Available: http://eprints.utar.edu.my/1619/1/Microsoft_Word__A_STUDY_OF_PROJECT_DELAY_IN_SUDAN.pdf. Access :June 1, 2017.

OMRAN A.; ABDALRAHMAN S.; PAKIR A. (2012) Project Performance in Sudan Construction Industry: A Case Study. Academic Research Journals (India), v.1, n.1, p. 55- 78.

OYEWOBI, L.O.; OGUNSEMI, D.R., (2010) Factors influencing rework occurrence in construction: A study of selected building projects in Nigeria: Journal of Building Performance, v. 1, n. 1, p. 1-20.

PALANEESWARAN, E. (2006) Reducing Rework to enhance Project Performance Levels", Proceedings of the one day Seminar on "Recent Developments in Project Management in Hong Kong."

ROGGE, D. F.; CAUSES, U. o. T. A. A. C. I. I.; TEAM, E. o. F. R. R.; UNIVERSITY, O. S. (2001) An investigation of field rework in industrial construction. Report No.RR153-11, Cll, Austin, Texas. 
ROUNCE, G. (1998), Quality, waste, and cost consideration in architectural building design management. International Journal of Project Management, v. 16, n. 2, p. 123-127.

SAIDU, I.; SHAKANTU, W. M. W. (2016c) The contributions of Material Waste to project-cost Overrun in Abuja, Nigeria. Acta Structilia, v. 23, n. 1, p. 99-113.

SAIDU, I.; SHAKANTU, W.M.W. (2016a) A Study of the Relationship between Material W aste and Cost Overruns in the Construction Industry. The 9th CIDB Postgraduate Conference Cape Town, South Africa. Emerging trends in construction organisational practices and project-management knowledge area. Edited Windapo, A. O., p. 124-134, Feb, 2-4, 2016.

SIMPEH, E. K. (2012) An Analysis of the Causes and Impact of Rework in Construction Projects. A Thesis submitted Cape Peninsula University of Technology, South Africa. Available: http://hdl.handle.net/11189/1054. Access: 10/12/2016.

SMALLWOOD, J. J. (2000) A study of the relationship between occupational health and safety, labour productivity and quality in the South African construction industry. Published PhD (Construction Management) thesis, University of Port Elizabeth, Port Elizabeth. Available:

http://hdl.handle.net/20.500.11892/155953. Access: 1/12/2016.

SPACEY, J. (2016) What is a Risk Trigger? Available:

http://simplicable.com/new/risk-trigger, Access: 8th March, 2017.

The NEA Research Bulletin (1960) Small-Sample Techniques. v. 38, p. 99.

THODE, H.C. (2002) Testing for Normality. Marcel Dekker, New York. Available: http://dx.doi.org/10.1201/9780203910894.

WALKER, D. H. T. (1994) An investigation into the factors that determine building construction time performance. $\mathrm{PhD}$ thesis, Department of-Building and Construction Economics, Faculty of Environmental Design and Construction, Royal Melbourne Institute of Technology, Melbourne, Australia. Available:

http://dx.doi.org/10.1080/01446199500000030. Access: $7^{\text {th }}$ October, 2016.

WASFY. M. A. F. (2010) Severity and impact of reworking, a case study of a residential commercial tower project in the Eastern Province-KSA. Master Thesis. Dhahran, Saudi Arabia: King Fahd University of Petroleum \& Minerals, p.1122. 